\title{
Management of lucerne in the cool season
}

J.G.H. WHITE and W.J. LUCAS* Plant Science Department, Lincoln University

\begin{abstract}
The performance of dormant and winter-active lucerne (Medicago sativa L.) cultivars was compared under sheep grazing in 2 experiments during the cool season. The objectives were to define the cool season management required for winter active cultivars in sheep farming systems. The 'winter-active cultivars Matador and Rere yielded 1760 and $1220 \mathrm{~kg}$ DM/ha compared with 890 and $760 \mathrm{~kg}$ from Wairau and Saranac respectively in mid-winter, while the reverse occurred in spring when dormant cultivars yielded $50 \%$ more than the winteractive. This was related to differing levels of non-structural carbohydrates in roots, which had declined to insignificant levels in Rere and Matador by early spring. June grazing increased spring yields of Wairau by $35 \%$ due to control of overwintering aphids, but reduced yield of Rere by $25 \%$ due to effects on root reserves. Early September grazing greatly reduced subsequent lucerne yields at late October and- early- -December grazings, and increased the content of weeds. Our findings show that if farmers graze winter-active lucerne with sheep in winter the advantage in production disappears in spring. Cool-season management which combines the use of dormant and winter-active lucernes is discussed.
\end{abstract}

Keywords winter-active lucerne, dormant lucerne, cool-season grazing, root reserves, lucerne grazing management

\section{Introduction}

On dryland farms where lucerne is grown as an important proportion of the grazed herbage, there has always been the need to provide alternative, higher-cost feeds in the cool season because of low growth rate of the lucerne plant. A number of past experiments have examined cool-season grazing of

*Present address: Ivon Watkins-Dow Ltd, Christchurch lucerne, the results of which have been somewhat contradictory. In the cold winter climate of Omarama, Mackenzie Country, Douglas (197 1) found that early spring production was best when lucerne remained uncut in autumn, but the depression was less when lucerne was cut after frost had stopped further growth. Marble et al. 1(1989), in the Mediterranean climate of central California obtained similar results, but found that the depression to the first spring cut was more than offset by the extra production from a single winter harvest. At Winchmore, Janson $(1974,1975)$ also showed that autumn-early winter grazing depressed early spring growth, but in contrast to Douglas (1971) and Marble et al. (1989) late April grazing reduced yield less than grazing in early June.

These findings were overshadowed in New Zealand by the necessity to control overwintering aphids by hard grazing in early June (Smallfield et al. 1980; Wynn-Williams et al. 1989). This practice is now widely adopted by farmers, as any depression to early spring growth from a June grazing is likely to be more than offset by the increase in spring yield from reduced aphid attack. In any case, depression to early spring growth from autumn or early winter grazing is most $^{-}$evident ${ }^{-}$in-September-and-largely_disappears_if the lucerne is allowed to grow until late October before being defoliated (Janson 1975; Smallfield et al. 1980). This was confirmed over 4 years by WynnWilliams et al. (1989), who showed that 1-2 weeks' heavy grazing in mid-winter had no effect on late October yields.

The more widespread use of winter-active cultivars for grazing in New Zealand has necessitated further study of current cool-season management systems, as nearly all the cultivars used in previous studies have been winter dormant. White \& Lucas (1989) have shown in cutting trials that if winter-active lucernes are defoliated in autumn and winter, they will produce less herbage in early spring than dormant cultivars. This paper describes two trials where lucerne cultivars of varying cool-season activity were compared under grazing.

\section{Treatments and sampling}

In the first experiment the winter dormant cultivar Wairau was compared with Rere, a winter-active and aphid-tolerant cultivar, under 4 cool-season grazing management treatments over 2 years. The 
treatments, each replicated 4 times, were: grazed June; grazed September; grazed June and September; no grazing.

During the rest of the year the $500 \mathrm{~m}^{2}$ plots were grazed similarly with sufficient sheep to defoliate the lucerne to $3 \mathrm{~cm}$ in 10 days of grazing, after which they were spelled for 42 days. The last grazing before treatments were imposed occurred in April each year.

Before each grazing, samples were taken for dry matter (DM) yield and botanical analysis. Aphid populations were monitored during the 1982 spring.

In the second experiment, 4 lucerne cultivars, Saranac, Wairau, Rere and Matador, ranging from low to high cool-season activity, were compared under common grazing in April, early July and midSeptember. Plots measured $108 \mathrm{~m}^{2}$, each treatment being replicated 4 times. At the July and September grazings, DM yield was measured and 30 plants removed from each treatment for soluble carbohydrate determinations from the top $20 \mathrm{~cm}$ of each tap-root.

Both experiments were conducted on a Templeton silt loam soil under dryland conditions on the Lincoln University Research Farm. The mean annual rainfall at the site is $670 \mathrm{~mm}$, but during the first 7 months of 1982 only half the expected rainfall occurred. Normal conditions prevailed during the rest of the experiment.

\section{R esults}

Grazing in June affected Wairau and Rere quite differently in spring production (Table 1). When compared with the ungrazed treatment, the yield of Wairau was increased at the October grazing while that of Rere was reduced. While Rere produced $57 \%$ more DM than Wairau in June, Wairau produced nearly double that of Rere in October after the June grazing. Without a June grazing, yields were similar.

Table 1 DM yields (kg/ha) of Wairau and Rere lucernes after a June 1982 grazing.

\begin{tabular}{|c|c|c|c|c|}
\hline \multicolumn{2}{|c|}{ Treatment } & June 13 & $\begin{array}{r}\text { September } 9 \\
\text { (interim cut) }\end{array}$ & \multirow{2}{*}{$\begin{array}{c}\text { October } 20 \\
\text { (graze) }\end{array}$} \\
\hline Wairau & No grazing & $g-$ & 1030 & \\
\hline \multirow{3}{*}{ Rere } & Grazed & 460 & 1700 & 3130 \\
\hline & No grazing & $g-$ & 1070 & 2220 \\
\hline & Grazed & 720 & 1100 & 1670 \\
\hline \multirow{2}{*}{\multicolumn{2}{|c|}{$\begin{array}{l}\text { CV\% } \\
\text { SEM } \\
\end{array}$}} & 8.0 & 21.3 & 7.9 \\
\hline & & 47 & 260 & 130 \\
\hline
\end{tabular}

The early September grazing greatly reduced DM yield of both cultivars at the late October grazing (Table 2). These differences were still present in early December, but had disappeared by mid-summer. The yield decline was largely due to a major reduction in shoot length of both cultivars (Table 3). The combination of grazing in both June and early September reduced yield still further in both cultivars in October when compared with a September-only grazing, but had no effect subsequently.
Table 2 Effects of cool-season grazing on subsequent lucerne production (kg DM/ha) 1982/83 (mean of two cultivars).

\begin{tabular}{lcccc}
\hline Treatment & Oct 20 & Dec 9 & Jan 25 & $\begin{array}{c}\text { Total } \\
\text { (Sept, Oct \& } \\
\text { Dec grazing) }\end{array}$ \\
\hline No grazing & 2270 & 3040 & 2140 & 5310 \\
June 13 & 2400 & 2590 & 2120 & 4990 \\
September 9 & 1130 & 1780 & 1870 & 3960 \\
June \& Sept & 800 & 1710 & 1810 & 3910 \\
\hline cv \% & 7.9 & 22.5 & 25.6 & \\
SEM & 130 & 312 & 308 & \\
\hline
\end{tabular}

Table 3 Effect of early September grazing on shoot length (cm) and number per plant on 20 October 1982

\begin{tabular}{llcc}
\hline Treatment & Shoot length & $\begin{array}{c}\text { Shoot } \\
\text { number }\end{array}$ \\
\hline Wairau & No grazing & 30 & 7 \\
& Grazed & 12 & $\mathbf{1 1}$ \\
Rere & No grazing & 32 & 5 \\
& Grazed & 13 & 8 \\
\hline c v \% & 10.8 & 8.4 \\
SEM & & 2.3 & 0.7 \\
\hline
\end{tabular}

When aphids were measured on 19 October, the June grazing had reduced the number per stem from 87 to 29 in Wairau, and 44 to 18 in Rere.

The weed content of both cultivars increased in early-September-grazed treatments, and after 2 years of this management differences were substantial (Table 4). The weed content of Rere became much greater than that of Wairau as the stand thinned due to development of crown rot.

Table 4 Weed content ( $\%$ of total DM) of Wairau and Rere lucernes on 9.1.84 after 2 years of cool-season grazing management.

\begin{tabular}{lcc}
\hline Treatment & Wairau & Rere \\
\hline No grazing & 1 & 16 \\
June & 3 & 35 \\
September & 15 & 35 \\
June \& September & 39 & 47 \\
\hline c v \% & \multicolumn{2}{c}{26.9} \\
SEM & \multicolumn{2}{|c}{8.7} \\
\hline
\end{tabular}

In the second grazing experiment DM yields in July reflected the differing cool-season activity of the four cultivars, with the very winter-active cultivar Matador yielding more than twice the dormant Saranac (Table 5). DM yields were reversed by September, when Saranac yielded $47 \%$ more than Matador. The non-structural carbohydrate levels in the roots of Matador and Rere were only half those of Saranac and Wairau in July, and had dropped to very low levels by September.

\section{Discussion and conclusions}

These results strongly support the results of White \& Lucas (1989) and show that if winter-active lucernes 
Table 5 DM yields (kg/ha) and non-structural carbohydrate content (\%) of root DM) of four Lucerne cultivars at July and September grazings, 1982.

\begin{tabular}{|c|c|c|c|c|}
\hline \multirow[b]{2}{*}{ Cultivar } & \multicolumn{2}{|c|}{ July 15} & \multicolumn{2}{|c|}{ September $\mathbf{2 1}$} \\
\hline & DM yield & $\begin{array}{l}\text { Non-structural } \\
\text { carbohydrate }\end{array}$ & DM yield & $\begin{array}{l}\text { Non-structural } \\
\text { carbohydrate }\end{array}$ \\
\hline $\begin{array}{l}\text { Saranac } \\
\text { Wairau }\end{array}$ & $\begin{array}{l}760 \\
890\end{array}$ & $\begin{array}{l}31 \\
23\end{array}$ & $\begin{array}{l}1220 \\
1160\end{array}$ & $\begin{array}{r}14 \\
8\end{array}$ \\
\hline Rere & 1220 & 12 & 820 & 2 \\
\hline Matador & 1750 & $\overline{11}$ & 830 & $\overline{1}$ \\
\hline $\mathrm{cv} \%$ & 10.1 & 8.4 & 7.7 & 10.2 \\
\hline SEM & 117 & 1 & 78 & 1 \\
\hline
\end{tabular}

are grazed in winter, their spring production is much less than that of dormant cultivars. Although differences may still occur without winter grazing (Lucas 1984; White \& Lucas 1989), the recovery growth which follows a winter grazing of winteractive cultivars depletes carbohydrate reserves almost completely and is the major reason for the low spring yields (Tables 1 and 5). Dormant cultivars, on the other hand, retain high reserves through winter and are thus able to produce higher spring yields.

The higher yield of Wairau in spring after the June grazing (Table 1) was almost certainly due to the significant reduction in overwintering aphid numbers. Any similar effect on Rere was overshadowed by the negative effects of the June grazing on root reserves. The positive effects of June grazing on spring production and aphid populations of the winter dormant Wairau confirms the results of Smallfield et al. (1980) and Wynn-Williams et al. (1989), which showed that June grazing is a sound management practice for both utilisation of lateautumn grown DM and for aphid control. However, it may well be advantageous to-spell -dormant cultivars in late autumn, i.e. late April-May while they are still growing, as advocated by Douglas (1971) and Marble et al. (1989), and thus avoid depletion of root reserves at this time.

Our findings confirm that winter-active cultivars should be managed quite differently from dormant cultivars in the cool season. If their extra growth is utilised by animals in the March-June period, then they must be spelled from grazing in spring until late October (White \& Lucas 1989) when carbohydrate reserves will have been restored. Farmers may thus develop a system of grazing winter-active cultivars in April-May, both winter-active and dormant cultivars in June, dormant cultivars in early October and winter-active cultivars in late October.

Avoiding the grazing of lucerne in July-August would still seem important as severe grazing in July (Palmers 1976; Wynn-Williams et al. 1989) is known to reduce spring growth significantly. Our experiment has shown that an early September grazing significantly reduces lucerne production for the rest of the spring (Tables 2 and 3). Grazing at this time should be avoided if at all possible and alternative feeds such as saved pasture or greenfeed used instead. Regular early spring grazing of a luceme stand will reduce lucerne vigour and increase weed invasion (Table 4).

\section{ACKNOWLEDGEMENTS}

The authors wish to thank G. Meijer, A.V. Jones, D.J. Heffer and S.E. Hines for technical assistance, Dr G.P. Savage for advice on carbohydrate analyses, and $\mathrm{Mr}$ B.G. Love for statistical advise. This work was supported by a D.S.I.R. research contract.

\section{REFERENCES}

Douglas, J.A. 1971. Autumn lucerne management - effect on early spring production. $\mathbf{N Z}$ agricultural science 6 (2): $13-15$.

Janson, C.G. 1974. Lucerne management for the critical spring period under light land grazing. Proceedings of the NZ Grassland Association 36: 66-72.

Janson, C.G. 1975. Influence of autumn-winter lucerne management and overdrilled "Grasslands Tama" on spring herbage yields. under. irrigated and dry conditions. NZ journal of experimental agriculture 3 : 229-234.

Lucas, W.J. 1984. Cool-season management of a winteractive lucerne cultivar. M Appl Sc thesis, Lincoln College, University of Canterbury.

Marble, V.L.; Schoner, C.A.; Peterson, G. 1989. Effect of fall/winter harvest on alfalfa (Medicago sativa L.) productivity and persistence in a Mediterranean climate. Proceedings of the XVI International Grassland Congress: 597-598.

Palmer, T.P. 1976. Annual weeds in established Lucerne. Proceedings of the 29th NZ Weed and Pest Control Conference: 5-8

Smallfield, B.M.; White, J.G.H.; Penman, D.R. 1980. Effect of cool season grazing on Lucerne production and aphid populations. Proceedings of the NZ Grassland Association 41: 42-49.

White, J.G.H.; Lucas, W.J. 1989. Cool season grazing of winter-active Iucernes. Proceedings of rhe XVI International Grassland Congress: 387-388.

Wynn-Williams, R.W.; Rea, M.B.; Purves, R.G.; Hawthorne, B.T. 1989. Influence of winter treading on lucerne. Proceedings of the XVI International Grassland Congress: 10 19- 1020. 